American Journal of Applied Sciences 7 (12): 1528-1531, 2010

ISSN 1546-9239

(C) 2010 Science Publications

\title{
The Nascent Development of Ecotourism in Lagong Hill
}

\author{
Ah-Choy Er \\ School of Social, Development and Environmental Studies, \\ Faculty of Social Sciences and Humanities, University Kebangsaan Malaysia \\ 43600 Bangi, Selangor Darul Ehsan, Malaysia
}

\begin{abstract}
Problem statement: The nascent development of ecotourism in Lagong Hill faces an interesting challenge. The aim of this research note is to evaluate the nascent development of ecotourism in Lagong Hill, Malaysia based on the common core precepts of ecotourism. Approach: The research methods comprise of secondary data collection and field survey via an in-depth interview with selected key informants. This is aided by on-field observation to verify and complement the research findings. Results and Discussion: The ecotourism park management has exhibited environmentally responsible behavior. Nature conservation, tourism management, solid waste management and water utilization adopt the core precepts of ecosystem protection, minimal environmental impact and environmental education. However, there is a lack of outreach towards the indigenous people who are residing within this forest reserve. The Orang Asli, the indigenous people of this area, have profound and in-depth knowledge of the forest and its terrains. This local knowledge and cultural heritage has yet to be tapped as part of community-based ecotourism. In addition, there is a lack of scientific research on the impact of quarrying and timber production on ecotourism. Conclusion: The ecotourism venture in Lagong Hill fulfills the core precepts of ecotourism with the exception of the participation of indigenous people. There is a need to inculcate community-based ecotourism rather than primarily focusing on environmental or economic impacts. More scientific research is required to determine carrying capacity, and the impact of quarrying and timber production on ecotourism.
\end{abstract}

Key words: Community-based ecotourism, indigenous people, forest, sustainable development

\section{INTRODUCTION}

There are varied definitions of ecotourism. However, the definitions by the Quebec Declaration of Ecotourism, The International Ecotourism Society, Honey (2008) and Wight (1993) overlap with each other. The common core precepts in these varied definitions are:

- Conservation of natural and cultural heritage via ecosystem protection

- Empowerment and provision of financial benefits for local communities and indigenous people via participation in ecotourism activities

- Minimal environmental impact and ecotourism is often optimized on a small-scaled basis

- Environmental and cultural education and respect for travelers

However, the development of ecotourism has sometimes resulted in malpractices leading to greenwashing. For example, jungle tourism or nature tourism packaged from a marketing perspective in the guise of ecotourism in most cases do not fulfill the core precepts of ecotourism.

The question that begets is the fulfillment of the common core precepts of ecotourism as outlined above. This nascent development and the learning curve it is on poses an interesting challenge for this ecotourism venture. As such the aim of this research note is to evaluate the nascent development of ecotourism in Lagong Hill, state of Selangor, Malaysia.

Area of Study: The area of study, Lagong Hill is gazetted as a permanent forest reserve with an area of 3624.1 ha. and is rich in forest biodiversity ( $\mathrm{Er}$ and Jahari, 2009). The altitude for Lagong Hill ranges from $290 \mathrm{~m}$ to approximately $575 \mathrm{~m}$ at its peak. Lagong Hill Forest Reserve acts as a water catchment area for Buloh River, Jinjang River, Kuang River and Keroh River. The economic activities within Lagong Hill Forest Reserve are ecotourism (one concessionaire), quarrying (six concessionaires) and timber production (one concessionaire). The two indigenous villages in Lagong Hill Forest Reserve are namely Kampong 
(village) Orang Asli Ulu Keledek and Kampong (village) Orang Asli Bukit Lagong belonging to the Temuan tribe. The indigenous people in Malaysia are collectively known as Orang Asli.

The main foci of this research note are ecotourism and the indigenous people residing within Lagong Hill. These two have been identified based on the core precepts of ecotourism as outlined above. The other economic activities, namely quarrying and timber production, will be viewed from the perspective of their negative knock-on impact, if any, on ecotourism (Demir and Ozturk, 2005; AL-Nawafieh, 2005).

Ecotourism comes under the aegis of the Commonwealth Forest Park, formed in conjunction with the 14th Commonwealth Forest Conference in 1993 with an area of approximately 260 hectares. This park is managed by a concessionaire with physical facilities comprising of a resort with 24 rooms, a multifunctional hall, a horse stable and an adjacent horse-track, a hanging canopy bridge, camping ground and forest treks. The main forms of income generation are conducting motivational camps for students, corporate training through experiential learning, guided nature walks in small groups, camping and horse riding related activities (Er and Jahari, 2009).

The forest is very much embedded in the lives of the indigenous villagers and contributes in no small measure to its social fabric and cultural heritage. For the older generation with either no or little formal education, the forest is their source of livelihood in terms of gathering forest produce and hunting of wild life and fishing. The yield from the forest is either for personal consumption or to be traded in the nearby market. As the young to mid generations have better access to formal education, many have found work in the public and private sector. Some of them work in the quarries and timer camps located within this forest reserve and they, collectively, are working as manual laborers and not holding any supervisory or managerial position. Practically, all of the working indigenous people residing here will during their free time, especially weekends, would indulge in their favorite past-time by entering the forest to either hunt or gather forest produce mainly for their personal consumption. The forest is also a warehouse for the construction and maintenance of houses for some of the indigenous villagers. Rattan, bamboo and certain types of leaves are utilized for the construction and maintenance of such houses. However, those who enjoy a better standard of living have constructed brick houses for their families.

\section{MATERIALS AND METHODS}

The research method adopted in this research note has a two-prong approach. The first step is the collection and analysis of secondary data pertaining to Lagong Hill Forest Reserve. This includes secondary data on ecotourism, indigenous people, quarrying, timber production and flora cum fauna located within Lagong Hill Forest Reserve. The second step is carrying out a field survey via an in-depth interview with key informants, namely the management of the eco-tourism concessionaire, district forestry officials, Tok Batin (head villagers) of the two Orang Asli indigenous villages and selected indigenous villagers who are knowledgeable of developments within and in the immediate surroundings of Lagong Hill Forest Reserve. This is aided by on-field observation to verify and complement the research findings.

\section{RESULTS AND DISCUSSION}

The results and discussion will be based on the following:

Ecotourism Management: The ecotourism management is very sensitive towards the environment and biodiversity within the Commonwealth Forest Park. Nature conservation is given the highest priority and human resources are sensitive of their impact on the environment. Collectively, they try to impart the minimum carbon footprint based on their daily operational activities.

The motivational camps and corporate training programs often incorporate a guided jungle trekking element. The trained guides would instruct the trainees not to litter along the trail and carry back their own wastes for proper disposal. In addition, the guides would also collect litter found along the trail. The solid waste generated by visitors in the resort area is brought to the foothills for proper disposal. This is also inclusive of food wastes and remnants which has the possibility of being composed into organic fertilizer.

River water is channeled to the resort for its daily operation. Waste water generated from cafeteria operation and lodging is filtered prior to being channeled to the septic tank. This is to ensure that the wastewater will not lead to odor pollution. In addition, the septic tank is treated monthly with chemicals to eradicate threats to human health. This is to ensure that the river water is not contaminated as Lagong Hill Forest Reserve is a water catchment area.

The electrical energy used in this resort comes from the national grid. Peak usage is during the 
weekends and school holidays as there are more tourist arrivals. Renewable energy like solar energy is not tapped as the investment cost is high and the pay back period would be long. At this juncture, Lagong Hill is not well known nationally and internationally and the concessionaire does not have the deep pocket for this eco-friendly measure.

Even though horse riding cannot be classified as part of ecotourism, the waste management methods adopted by the concessionaire lead to minimal environmental impact. Sawdust is used as a form of layering in the stable to absorb urine and to capture faces. This measure acts as a fly deterrent as flies can lead to health problem and can be a nuisance factor. The sawdust will be replaced every two days and the soiled sawdust will be burnt at a designated spot. However, controlled burning with air filtration in a closed environment would be a better alternative. The drainage system in the resort is closed when the horses are being bathed. This wastewater is then filtered prior to being channeled to the septic tank. The closure of the drainage system is to ensure that this wastewater will not lead to river pollution as Lagong Hill Forest Reserve is a water catchment area.

Dried leaves, branches, rotting trunks and dead plants are gathered at designated spots among the trees to be converted into organic fertilizer. It could have been better if organic wastes like food wastes and organic remnants are composed into organic fertilizer and applied to trees and plants grown in the compounds of the resort.

The concessionaire has plans to build hostel facilities on existing cleared site without encroaching on forested areas. Building on existing cleared site helps in nature conservation but a troubling question in terms of the potential increased utilization of the park remains. Scientific base-line data with regard to carrying capacity is absent and very often it is based on capacity of physical facilities and manpower available to organize camps, corporate training and guided nature walks. This also happens as in the case of Mount Kinabalu in terms of defining carrying capacity (Er et al., 2010). There are already complaints of unguided day-trippers littering the forest trails and the need by concessionaire employees to regularly clean up the trails. This problem may be compounded as increased utilization often leads in tandem to increase waste generation cum attendant problem.

The management and supervisory staff of the ecotourism concessionaire are locals from the state of Selangor but not from Lagong Hill Forest Reserve. The housekeeping staffs comprise of locals who are staying in the nearby vicinity of Lagong Hill Forest Reserve and also foreign contract workers. High turnover is a perennial problem for housekeeping staff. The Orang Asli, the indigenous people of Lagong Hill Forest Reserve have not benefitted from employment opportunities in this ecotourism venture due to limited awareness or lack of access. Campbell (1999) asserted that a lack of intervention will limit the possibility of further benefit from ecotourism development. The livelihood of the Orang Asli revolves around the jungle from a historical and cultural context. They have kept to the traditional way of life by hunting, fishing, gathering food, medicine and tradable products like rattan from the forest. The Orang Asli will make ideal jungle guides and porters as they are well-verse with the terrains and ways of the forest. However, at this juncture, a handicap is the lack of ability to converse in English, a critical requirement to being a forest guide, as there is a growing number of foreign visitors.

Quarrying and Logging: Quarrying within this permanent forest reserve may have ramifications for the area in general. This can have a direct or indirect impact on ecotourism. As this is a relatively high altitude area, quarrying may have an impact on the water catchment functionality. Blasting to extract rocks during working hours may also have an impact on fauna, especially birds. In addition, forestry officials claimed that Reduced Impact Logging adopted in specific compartments within Lagong Hill Forest Reserve has reduced the problem of soil erosion. However, further scientific studies, especially in the area of hydrology, need to be carried out to determine the impact of quarrying and timber production on the environment and biodiversity (Jabbar and Chen, 2005; Sorensen et al., 2009).

\section{CONCLUSION}

As a general rule of thumb, the operational activities of this ecotourism venture fulfill the core precepts of ecotourism with the exception of the participation of indigenous people either as employees or business partners. There is a lack of outreach to integrate the Orang Asli as they have high employability due to their in-depth knowledge of the forest and their homes are in the immediate vicinity of the Commonwealth Forest Park. Community-based ecotourism needs to acknowledge the importance of social dimension rather than just primarily focusing on environmental or economic impacts (Scheyvens, 1999). Uniting conservation and community is one of the cornerstones of ecotourism. Learning of alternative perspective from the indigenous community, 
appreciation of their heritage and addressing current indigenous issues like raising the standard of living can help to empower the local community and foster synergistic community-based ecotourism (Theodoropoulou et al., 2008). However, the expansion of physical facilities need to take into consideration the carrying capacity from a scientific perspective (Libosada Jr, 2009) and not just from the number of visitors based on physical capacity. The nascent development of ecotourism in Lagong Hill Forest Reserve exhibits to a large extent environmentally responsible behavior by the ecotourism park management but more can be done on the social and scientific dimension such as renewable resources in progressing towards sustainable development. More scientific research, especially on hydrology, needs to be carried out on the impact of quarrying and timber production on sustainable development as it may have ramifications for ecotourism.

\section{ACKNOWLEDGEMENT}

This research is financed by the Fundamental Research Grant Scheme Code Number: UKM-XX-01FRGS0007-2006, Ministry of Higher Education and Malaysia.

\section{REFERENCES}

Er, A.C. and N.D. Jahari, 2009. The development of the tourism sector in Commonwealth Forest Park, Selangor: an analysis of competitive advantage determinants. In: Bio-Engineering and Ecosystem Sustainability, Adam, J.H., M. B. Gasim and Z. Sakawi (Eds.). Ecosystem Health Research Group and Bukit Fraser Research Centre, Malaysia, ISBN: 978-983-44502-1-2, pp: 291-305.

Er, A.C., A. Biun and J.H. Adam, 2010. The nascent development of ecotourism in Mount Tambuyukon. Proceeding of Mount Tambuyukon Scientific Seminar, Kota Kinabalu, Sabah, pp: 6-8.
Libosada Jr., C.M., 2009. Business or leisure? economic development and resource protectionconcepts and practices in sustainable ecotourism. Ocean Coastal Manage., 52: 390-394. DOI: 10.1016/j.ocecoaman.2009.04.004

Theodoropoulou, H., R. Mitoula, O. Astara and P. Kaldis, 2008. Applied issues of agritourism cooperation and sustainable endogenous development. Am. J. Applied Sci., 5: 1588-1594. ISSN: 1546-9239

Campbell, L.M., 1999. Ecotourism in rural developing communities. Ann. Tourism Res., 26: 534-553. DOI: $10.1016 / \mathrm{S} 0160-7383(99) 00005-5$

Honey, M., 2008. Ecotourism and Sustainable Development: who owns Paradise? 2nd Edn., Island Press, Washington, ISBN: 978-1597261258, pp: 33.

Al-Nawafieh, M.A., 2005. Development of ecological criteria of noise control with application of absorbents. Am. J. Applied Sci., 2: 443-446. http://www.aseanenvironment.info/Abstract/41014 943.pdf

Demir, M. and T. Ozturk, 2005. The situation and evaluation of forest harvesting methods in Turkey. Am. J. Applied Sci., 2: 449-503. http://www.scipub.org/fulltext/ajas/ajas22499503.pdf

Jabbar, M.T. and X. Chen, 2005. Soil degradation risk prediction integrating rusle with goe-information techniques, the cae of northern shaanxi province in china. Am. J. Applied Sci., 2: 550-556. http://www.scipub.org/fulltext/ajas/ajas22550556.pdf

Wight, P.A., 1993. Ecotourism: ethics or eco-sell. J. Travel Res., 31: 3-9. DOI: 10.1177/004728759303100301

Sorensen, P.B., R. Bruggemann, M. Thomsen, S. Gyldenkaerne and C. Kjaer, 2009. How to guide and assess risk reduction using risk characterization indicators. Am. J. Applied Sci., 6: 1255-1263. DOI: 10.3844/ajassp.2009.1255.1263

Scheyvens, R., 1999. Case study: ecotourism and the empowerment of local communities. Tourism Manage., 20: 245-249. DOI: 10.1016/S02615177(98)00069-7 